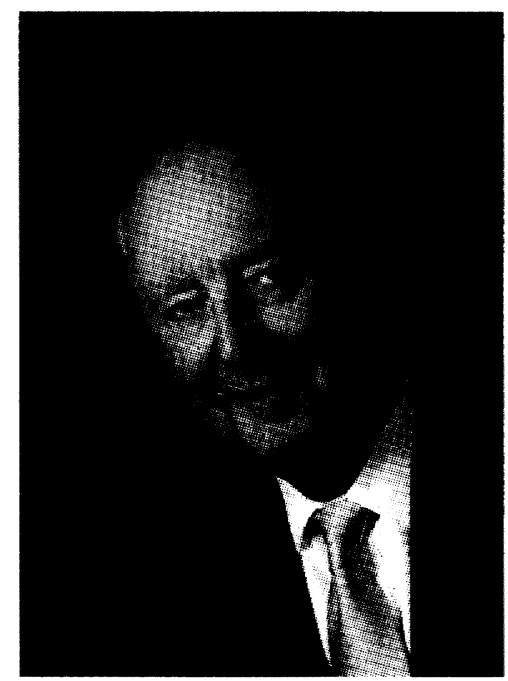

David Korn

David Korn (B.A., scl, M.D., $c l$, Harvard University) is the first ViceProvost for Research at Harvard University as well as Professor of Pathology at Harvard Medical School, positions he assumed on November 15, 2008. Prior to joining Harvard, Dr. Korn had served as the Chief Scientific Officer of the Association of American Medical Colleges (AAMC) in Washington, D.C. since January 15,2007 , and before that as the Senior Vice President for Biomedical and Health Sciences Research at the Association since September 1, 1997.

Dr. Korn served as Carl and Elizabeth Naumann Professor and Dean of the Stanford University School of Medicine from October 1984 to April 1995, and as Vice President of Stanford University from January 1986 to April 1995. Previously, he had served as Professor and Chairman of the Department of Pathology at Stanford, and Chief of the Pathology Service at the Stanford University Hospital, since June 1968. Dr. Korn has been Chairman of the Stanford University Committee on Research; President of the American Association of Pathologists (now the American Society for Investigative Pathology), from which he received the Gold-Headed Cane Award for lifetime achievement in 2004; President of the Association of Pathology Chairman; a member of the Board of Directors and of the Executive Committee of the Federation of American Societies for Experimental Biology; and a member of the Board of Directors of the Association of Academic Health Centers.

Dr. Korn was a founder and Chairman of the Board of Directors of the California Transplant Donor Network, one of the nation's largest Organ Procurement Organizations. More recently, he was a founder of the Association for the Accreditation of Human Research Protection Programs, a nonprofit corporation created to enhance and standardize the protection of 
human participants in medical and other scientific research. He has been a member of the Institute of Medicine of the National Academies of Science since 1989 and has served on numerous NAS and IOM committees; Dr. Korn was a founder of the IOM's Clinical Research Roundtable and is currently the co-chair of the NAS Committee on Science, Technology and Law. In 1996-97 Dr. Korn chaired a Special Subcommittee of the Science Board of the Food and Drug Administration to Review the FDA's Intramural Research Program, for which he received the Commissioner's Special Citation and the Harvey W Wiley Medal. From 1984 to 1991 he served as Chairman of the National Cancer Advisory Board, a position to which he was appointed by President Reagan. Dr. Korn is a Fellow of the AAAS and has served on its Council, and he was a member of the University Grants Committee of Hong Kong from 1998-2004, where he was Chairman of the Medical Subcommittee.

Dr. Korn served on the Boards of Directors of the Stanford University Hospital from October 1982 to April 1995, the Children's Hospital at Stanford from October 1984 to its closure, and the Lucile Salter Packard Children's Hospital at Stanford from October 1984 to April 1995 . He was a member of the Board of Directors of the California Society of Pathologists from 1983-86.

Dr. Korn has been a member of the editorial boards of the American Journal of Pathology, The Journal of Biological Chemistry, and Human Pathol$o g y$, and for many years was an Associate Editor of the latter. He has sat on many Society Councils and Boards. He has written many scientific articles, ranging from bacteriophage biochemistry and genetics to the biochemistry and molecular biology of DNA replication in human cells. During the past 2 decades his work, writings, and lectures have focused on issues of academic values and integrity, research integrity, health and science policy, and financial conflicts of interest in academic medicine. 


\title{
FinANCIAL CONFLICTS OF INTEREST IN ACADEMIC MEdicine: WhenCE THEY CAME, WHERE THEY WeNT
}

\author{
David Korn, M.D.
}

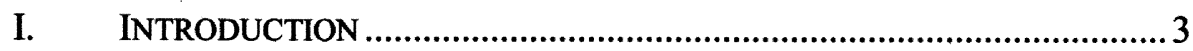

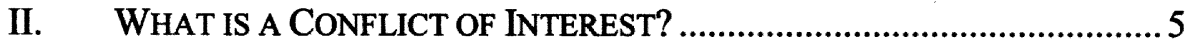

III. FINANCIAL CONFLICTS OF INTEREST: WHENCE THEY CAME .............6

IV. THE ACADEMIC COMMUNITY RESPONDS.........................................13

A. Accreditation Program for Human Research ............................ 13

B. AAMC Task Force on Clinical Research................................... 14

V. FINANCIAL CONFLICTS OF INTEREST, WHERE THEY WENT .............. 19

VI. ENTER THE NATIONAL INSTITUTES OF HEALTH (NIH)

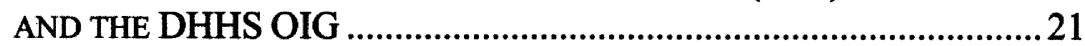

VII. THE ACADEMIC COMMUNITY SHOOTS ITSELF IN THE FOOT ..............23

VIII. NEW ACTORS ENTER THE FCOI MIX................................................25

IX. AGAIN, THE ACADEMIC COMMUNITY RESPONDS ............................28

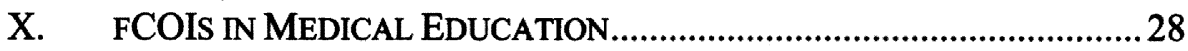

XI. THE SCIENTIFIC BASIS OF INFLUENCE AND RECIPROCITY: A

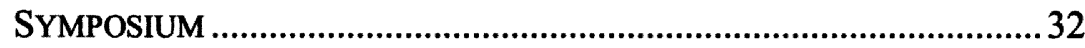

XII. FINANCIAL CONFLICTS OF INTEREST: WHERE THEY ARE,

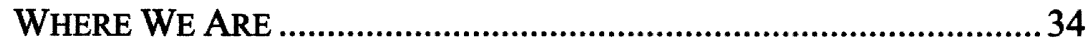

XIII. NIH ISSUES AN ADVANCED NOTICE OF PROPOSED RULE MAKING (ANPRM) FOLLOWED BY AN NPRM ……........................38

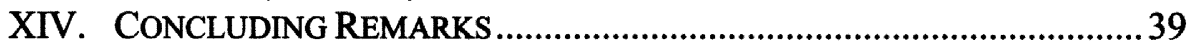

\section{INTRODUCTION}

Conflicts of interest are endemic in all professions, and the professions have over time developed normative behavioral and transactional processes to prevent or mitigate the effects of conflicts of interest from unduly influencing professional judgments, choices, and decisions. Consider the scientific method itself, as it evolved nearly five hundred years ago, demanding that communications of research findings provide complete descriptions of materials and methods used as well as the data obtained, in order to enable other scientists "skilled in the art" to test the reproducibility of the results, to build upon them or refute them. Perhaps it was because of an innate

* David Korn, M.D. is the Vice Provost for Research at Harvard University and Professor of Pathology at Harvard Medical School. On November 5, 2009, the Annual McDonald-Merrill-Ketcham Lecture/Indiana Health Law Review Symposium was held at Indiana University School of Law-Indianapolis. Dr. David Korn was keynote speaker of the event, we are grateful to have this article as an extension of his remarks. Some of the topics addressed have been updated by the author since his presentation to capture relevant intervening events. 
sense of human frailty that our forebears agreed both that scientific hypotheses (as opposed, for example, to religious dogmas) must be refutable and scientific observations, reproducible. Certainly, Sir Francis Bacon recognized these frailties when he wrote in 1620:

The human understanding is no dry light, but receives infusions from the will and affections; whence proceed sciences which may be called 'sciences as one would.' For what a man had rather were true he more readily believes .... Numberless, in short are the ways, and sometimes imperceptible, in which the affections color and infect the understanding. ${ }^{1}$

As I note later in this paper, more than 370 years would elapse before Bacon's insights would become, in a sense, formally codified by the marriage of Traditional Economics, erected on the principle of homo economicus, the "rational consumer," with Psychology that gave rise to the thoroughly disruptive discipline of Behavioral Economics.

It is important to recognize that the Academy provides no refuge. Conflicts of interest, the great majority of which do not, at least directly, involve money, are ubiquitous, indeed inevitable, in academic life, including in academic medicine. As I wrote a decade ago:

Successful scientists cannot be totally dispassionate about their work, nor can academic medical researchers be immune from the jumbled and often intense conflicting pressures that envelop them. These pressures, not primarily financial, include the desire for faculty advancement, to compete successfully and repetitively for sponsored research funding, to receive accolades from professional peers and win prestigious research prizes, and to alleviate pain and suffering. The last, which likely first led the researcher to choose an arduous academic career and then persist despite its demands, uncertainties, and disappointments, may be the most enduring pressure of all. All of these nonfinancial pressures may generate conflicts by creating strong bias toward positive results, and all of them may more powerfully influence faculty be- 
havior than any prospect of financial enrichment. ${ }^{2}$

Importantly, these kinds of pervasive academic conflicts are of little note or interest to the public. In contrast, financial conflicts of interest ("fCOIs") are well understood by the several different publics that academic medicine serves, and during the past three decades, recurring outbreaks of attention to fCOIs in academic medicine from the media, Congress, and the Administration have generated the increasing public concern that academic medicine now faces.

My purpose in this presentation on fCOIs in academic medicine is to provide a context to help the reader better understand from whence they came, where they went, and why they continue to be of such concern to the public and so vexing to academic medical institutions and their faculties, struggling to balance mixed public messages and conflicting public expectations.

\section{WHAT IS A CONFLICT OF INTEREST?}

There are many definitions of conflict of interest from which to choose, but the one I prefer is that offered in a recent report from the Institute of Medicine ("IOM"), one of the three components of the U.S. National Academies of Science: "A conflict of interest is a set of circumstances that creates a risk that professional judgments or actions regarding a primary interest will be unduly influenced by a secondary interest." A "primary interest" for academic medical scientists would be to protect the well-being of their patients and the integrity and credibility of their research. A "secondary interest" could be any of the examples listed above, but for the purpose of this manuscript, a secondary interest will be financial. Thus, an academic physician may be receiving payments from a pharmaceutical or medical device company that depends on the magnitude of his or her usage of the company's products. An academic medical scientist may also have a direct financial interest ranging from equity in a start-up company created from the discovery or from consulting or speaking payments from a vendor, in the outcome of the experiment, whether bench research or, for example, an early-phase clinical trial.

What is appealing about the IOM definition is its clarity that a conflict of interest ("COI"), financial or not, is a situation and not per se a judgment about the character or actions of an individual. When attempting to address fCOIs in a university, medical school, or teaching hospital, helping faculty and other personnel to understand this point becomes exceedingly im-

2. David Korn, Conflicts of Interest in Biomedical Research, 284 JAMA 2234, 22342237 (2000).

3. Conflict of Interest in Medical Research, Education, and Practice, InSTITUTE OF MEDICINE 46 (National Academies Press, 2009). 
portant, albeit very difficult. To this point, and recalling my quote from Francis Bacon, the noted behavioral economist, Professor George Loewenstein from Carnegie-Mellon University, has asserted that traditional economics assumes that professionalism and COIs are asymmetric motives in influencing behavior, and that persons who confront COIs are equipped to deal with them rationally. ${ }^{4}$ Behavioral economics posits a more complex model of decision-making, one that includes unconscious motives and other factors outside the control of a purely rational process. Biases are viewed as unconscious, or as many neuroscientists, concerned to avoid references to Freudian doctrine, would prefer, "unwitting" or "beneath awareness."

\section{FINANCIAL CONFLICTS OF INTEREST: WHENCE THEY CAME}

In the aftermath of World War II, inspired by the remarkable "path of the war-changing" discoveries (e.g., radar, sonar, napalm, cryptanalysis) from university laboratories working under federal research contracts and informed by the seminal report, Science: The Endless Frontier, ${ }^{5}$ authored by Vannevar Bush, who in 1940, while serving as the newly installed President of the Carnegie Institution of Washington, had become Director of the new federal Office of Scientific Research and Development, the federal government made the seminal decision that it had a legitimate role in funding basic research, and that the funding should flow through universities, where the performance of cutting edge research would be conjoined with the education of future generations of scientists. Probably no one precisely foresaw the enormous, world-leading American basic research enterprise that would result, led by what Columbia University Professor and former Provost Jonathan Cole has described in his new book, The Great American University. ${ }^{6}$ However, some senior academic leaders, especially from private universities, were concerned that "getting into bed with the government" in this way would have long-term adverse consequences, threatening the Academy's zealously protected autonomy and self-governance, and even its academic agenda. In response to these concerns, an agreement was negotiated to create what came to be dubbed the "Federal-Academic Research Partnership," under which the universities would retain their exclusive oversight of the conduct of federally sponsored research by their faculty members, while acknowledging the government's right to exercise

4. See The Scientific Basis of Influence and Reciprocity: A Symposium, 2007 Ass'N OF AM. MED. COLLEGES, June 7, 2007, (hereinafter Symposium) available at https://services. aamc.org/publications/index.cfm?fuseaction=Product.displayForm\&prd_id=215\&prv_id=26 2.

5. VANNeVAR Bush, Science: The Endless Frontier (1945), available at http://www.nsf.gov/od/lpa/nsf50/vbush1945.htm.

6. Jonathan R. Cole, The Great AMERICAN University: Its Rise to PrEeminence, Its INDISPENSABLE NATIONAL ROLE, Why It MUST Be PROTECTED (2010). 
due diligence that federal research funds were expended appropriately. From this agreement derived the "assurance mechanism" under which universities had only to "assure" federal research sponsoring agencies that they had in place dutifully enforced policies and procedures to enable their compliance with federal requirements. It was doubtless anticipated at the time that these requirements would remain relatively few and directed essentially exclusively at oversight of the expenditures of federal funds. This anticipation held true for about thirty years.

But beginning in the mid-1970s and continuing into the $1980 \mathrm{~s}$, there were an unfortunate series of episodes of scientific misconduct - or fraud that involved National Institutes of Health-funded biomedical research ("NIH"), some of which involved research on human subjects. These episodes became highly publicized, and they attracted the attention not only of the $\mathrm{NIH}$, but also of the cognizant congressional committees, especially in the House of Representatives. In a few of these cases, the perpetrators were discovered to have substantial fCOIs. A seemingly endless series of acerbic congressional hearings ensued, beginning with the Oversight and Investigations Subcommittee of the House Science Committee in 1981, during which the unfortunate conjunction of fCOIs with scientific fraud became ever more firmly cemented in media coverage and the minds of key Congresspersons. Arguably, the most compelling embodiment of this conjunction was the 1990 report from the House Committee on Government Operations, now the House Committee on Oversight and Government Reform, ${ }^{7}$ which catalogued the misconduct cases that had surfaced to date, entitled Are Scientific Misconduct and Conflicts of Interest Hazardous to Your Health? The conviction that fCOIs lead to research misconduct and, thus, to adverse effects on public well-being persists in the minds of the public to this day. Put most simply, fCOIs are bad; they lead to bad science; and bad science can result in harm to the public.

The cumulative hearings led to two major congressional actions that would forevermore alter the painstakingly negotiated terms of the FederalAcademic Research Partnership and the relationship of academic institutions and their faculty to federal research sponsors: the federal government would interpose itself into the oversight of the conduct of federally sponsored research by faculty investigators. The first action was contained in the 1985 reauthorization of the Public Health Act, ${ }^{8}$ containing the fundamental enabling legislation for the NIH, when Congress directed the Public Health Service ("PHS") to write a regulation defining and addressing misconduct in federally sponsored research. This directive, as expected, stimulated great concern among the leadership of academic research institutions

7. See H.R. REP. No. 688-101 (1990).

8. Health Research Extension Act of 1985, Pub. L. No. 99-158, §493, 99 Stat. 820 (1985). 
and professional scientific societies, and during the next nearly four years, there were difficult and often heated interactions between academic leadership and the PHS. In the forge of these interactions, the academic community came together on the goal of limiting the scope of the federal interest in research misconduct as much as possible, and this strategy proved successful. The final regulation issued in $1989^{9}$ was essentially confined to three behaviors that are relatively unambiguous and universally condemned across the community of scholars as research misconduct: fabrication, falsification and plagiarism, commonly referred to as "FFP." The regulation also established a formal process of institutional response to allegations of research misconduct, and it established in the PHS a new Office of Scientific Integrity ("OSI"), charged to oversee these institutional processes, review the institutions' final reports, conclusions and disciplinary actions, and pass judgment on the integrity, adequacy, and conclusions of the institutional processes. Shortly after the regulation was issued, the National Science Foundation ("NSF"), the second largest federal funder of academic scientific and engineering research, adopted its own misconduct regulation, which closely follows that of the PHS. ${ }^{10}$

Admittedly, FFP is limited. As the academic leadership desired, the rule does not purport to embrace the universe of misdeeds that university policies might properly consider "research misconduct," (e.g., authorship disputes, harassment of vulnerable members of research teams, sabotage of competitors' research, etc.). During the nearly four years of negotiation, and continuing through much of the 1990s, there were repeated efforts by federal officials and by clusters of academicians to broaden the scope of the federal rule. Final resolution did not occur until 2000, when the Office of Science and Technology Policy ("OSTP") in the Executive Office of the President issued a Notification of Final Policy ${ }^{11}$ on Research Misconduct that made important clarifying changes in the language of the 1988 regulation and reaffirmed the limitation of the rule's scope to FFP. With its publication in the Federal Register, the "Final Policy" became applicable to all federal agencies that sponsor research. Compliance with the rule is managed by the assurance process. Each year, research institutions must assure the government that they have in place dutifully enforced misconduct policies and procedures that are compliant with the regulation, and provide information about the number of allegations of misconduct they received

9. Public Health Service, Department of Health and Human Services, Grants, Policies of General Applicability, 42 C.F.R. §§ 50.101-607 (2011).

10. Public Welfare, Regulations Relating to Public Welfare, National Science Foundation, Research Misconduct, 45 C.F.R. $\$ 689$ (2010).

11. Office of Science and Technology Policy, Executive Office of the President; Federal Policy on Research Misconduct; Preamble for Research Misconduct Policy, Notification of Final Policy, 65 Fed. Reg. 76260 (Dec. 6, 2000), available at http://www.sc.doe.gov/ misconduct/finalpolicy.pdf. 
during the prior year, and the status of these allegations in the sequential institutional response procedures mandated by the rule.

In 1988, in harshly critical, many called them abusive, congressional hearings, led by Congressman John Dingell, then Chairman of the Oversight and Investigations Subcommittee of the House Energy and Commerce Committee, the matter was first raised of ordering the Department of Health and Human Services ("DHHS") to write a regulation addressing fCOIs in academic and other institutions that receive research and training grants, primarily from the NIH. Although formal authorizing language was not to appear until 1993, ${ }^{12}$ the DHHS responded to Mr. Dingell, and the battle lines with academe were redrawn. Difficult and often contentious negotiations would go on, and trial balloons would be launched and shot down, for nearly seven years before the PHS finally issued its regulation, entitled To Ensure the Objectivity of Research, in $1995 .^{13}$ It is noteworthy that the PHS remains to this day the only federal agency to have its own fCOI regulation. However, similarly to its action with respect to the PHS Research Misconduct regulation, the NSF very soon after issued its own essentially identical fCOI Guidance. ${ }^{14}$ Once again, the government was interposing itself into the oversight of the conduct of faculty investigators, and once again, the leadership of academic institutions and scientific societies fought to ensure that the regulation would be as minimally intrusive as possible. And the 1995 Rule was indeed light-handed!

In negotiating this rule, both the government and the academy were treading on unexplored terrain. At that time, there were no accepted landmarks or boundaries, such as specific magnitudes of related financial interests or specific circumstances generally agreed to create problematic fCOIs demanding institutional intervention, nor were there processes empirically demonstrated to be effective in dealing with fCOIs. Neither was there any consensus about the relative importance of fCOIs as compared to the plethora of non-financial COIs that I earlier addressed in leading faculty researchers to problematic behaviors, including research misconduct. In this domain, there was no ready equivalent of FFP. As described earlier, a COI, or fCOI, is a set of circumstances that creates a risk (often conditioned as an undue risk) of undue influence on professional decisions or actions. The existence of an fCOI is ultimately a matter of third-party (the "reasonable observer" so favored in law) perception or judgment, and perceptions and

12. NIH Revitalization Amendments of 1990, H.R. 5661, § 151 (1990) (containing authorizing language but did not become law); NIH Revitalization Amendments of 1992, H.R. 2507, § 154 (1992) (enacting authorization, however, both the FDA and the NIH were already well along in drafting their respective rules).

13. See 42 C.F.R. $\S \S 50.101-607$ (2010); 45 C.F.R. $\$ 94$ (2010).

14. National Science Foundation, Office of Budget, Finance \& Award Management, National Science Foundation Grant Policy Manual, Section 510 (2005), available at http://www.nsf.gov/pubs/manuals/gpm05_131/gpm05_131.pdf. 
judgments are awfully hard to regulate. In the end, after nearly seven years of heated deliberations and several rejected federal proffers, the government and academic leadership agreed to define, entirely arbitrarily, specific magnitudes of financial interests that relate to an investigator's federally funded research as "Significant Financial Interests" ("SFIs") (thus, $\$ 10,000$ or more income in a year from, or five percent equity in, a publicly traded company). The institutions would require faculty members annually and whenever they submitted a federal research proposal to identify and disclose such related SFIs, and if the institution determined that the SFI created a conflict with the proposed research project, it would deal with the fCOI by eliminating, reducing, or managing it before the conflicted investigator could begin spending funds from an awarded research grant. The regulation required only that the institution notify the funding agency (e.g., the NIH) that it had identified an fCOI related to a specific research grant and had dealt with it before permitting expenditure of the awarded funds. No further details were required, and although the regulation did empower the agency to request additional information, experience showed that this would occur infrequently.

During these prolonged negotiations, public attention to fCOIs in biomedical research had begun to wane, but the relative quietude ended abruptly in the latter $1990 \mathrm{~s}$, when a series of scathing federal reports focused attention on research involving human subjects and raised questions about how effectively the well-being of these research subjects was being protected under the extant federal regime by academic investigators and their institutions. First out of the gate was the report of a federal commission ${ }^{15}$ chaired by renowned ethicist, Ruth Faden, a Professor and Dean in the Johns Hopkins University School of Public Health, that had been charged with investigating secret experiments conducted by the U.S. military during WWII on U.S. civilian populations. The findings were damning and widely publicized. The commission, concerned by their findings of potentially dangerous and large-scale exposures of non-consented individuals to irradiation and microbial pathogens, decided toward the end of their investigation to conduct a "quick and dirty" examination of the then current state of "informed consent" by collecting informed consent documents from several dozen major research institutions. From their review, the commission concluded the informed consent process was seriously defective.

There followed three highly critical reports, two from the DHHS Office of Inspector General ("OIG") ${ }^{16}$ and one from the then General Ac-

15. ADVISORY COMMITTEE ON HUMAN RADIATION EXPERIMENTS, FINAL REPORT OF THE Advisory Committee on Human Radiation Experiments (U.S. Gov't Printing Office, 1995).

16. Off. Of the InSPector Gen., Dep't of Health and Human Serv., OEI-01-9700193, InstituTIONAL REVIEW BOARDS: A TIME FOR REFORM (1998), available at http://oig.hhs.gov/oei/reports/oei-01-97-00193.pdf [hereinafter INSTITUTIONAL REVIEW 
counting Office ("GAO"), ${ }^{17}$ all of which questioned the robustness and effectiveness of academic institutions' oversight of and diligence in protecting the wellbeing of their human research subjects, and the adequacy of their support for their Institutional Review Boards ("IRBs"). Applicable federal regulations ${ }^{18}$ require that all proposed research on human subjects that is not defined in the regulations as "exempt" must be reviewed, approved, and overseen by an IRB. Prospective research subjects must give their "informed consent" willingly and without coercion to participate in the research. The regulations and extensive subsequent guidance from the federal oversight bodies (during the 1990s, the Office of Protection from Research Risks [("OPRR") in NIH]; since 2000, the Office of Human Research Protections (“OHRP"), an independent component of the PHS) address in great detail what constitutes an acceptable informed consent process and its documentation. The IRB closely examines research proposals and informed consent documents to determine whether any of the investigators have fCOIs, whether the research is being performed to contribute to general knowledge (i.e., to be published), whether experimental risks have been appropriately minimized and adequately explained to prospective subjects, and whether the research will necessarily expose the subjects to more than minimal risk, and, if so, whether specific modifications of the protocol or protective measures must be implemented before the research can proceed. The primary duty of the IRB system is to protect the well-being of human research subjects and ensure that proposed research is conducted in conformity with the highest ethical principles as well as scientific standards - yet one of the OIG reports proclaimed that the "[IRB system] is in jeopardy." 19

These federal reports raised a new and pivotal question, previously unaddressed, about the ability of IRBs - institutional bodies - to fulfill their obligations in circumstances in which their institutions themselves have financial interests in proposed research involving human subjects. All of the mishaps noted earlier, which had so riveted the attention of the government and the media on fCOIs in federally sponsored research, had involved the fCOIs of individual researchers. And the 1995 fCOI regulation addresses only individual fCOIs. But now, in the late 1990s, for the first time, the financial interests of the institutions themselves - of the universities, the

BOARDS]; OFF. OF THE INSPECTOR GEN., Dep'T OF HEALTH AND Human SERV., OEI-9700197, PROTECTING HuMAN SUBJECTS: STATUS OF RECOMMENDATIONS (2000), available at http://oig.hhs.gov/oei/reports/oei-01-97-00197.pdf.

17. U.S. GeNERAL ACCOUNTING OFFICE, GAO/HEHS-96-72, SCIENTIFIC RESEARCH: Continued Vigilance Critical to Protecting Human SubJects (1996), available at http://www.gao.gov/archive/1996/he96072.pdf.

18. The PHS, as well as the scientific community, commonly refers to 45 C.F.R. $\S 46$ (2010) as the "Common Rule" because of its adoption by seventeen federal agencies that sponsor human subjects research; the exception is the FDA, which has its own variant of the Common Rule in 21 C.F.R. $\S 50$ (2010).

19. INSTITUTIONAL REVIEW BOARDS supra note 16, at 4. 
medical schools, the teaching hospitals - and the fCOIs they could generate, institutional fCOIs, had been placed squarely into the public spotlight. Recall that under the terms of the Federal-Academic Research Partnership the government had delegated to the academy the principal, if not exclusive, authority to oversee faculty conduct of federally sponsored research, but if the academy had its own financial interests in that research, did that not generate institutional fCOIs? And in the presence of such institutional fCOIs, how could the public be certain the institutional processes and bodies that implemented and assured institutional oversight were not being biased and could still be trusted? The Clinton Administration early in its second term (October 1995) had established the National Bioethics Advisory Commission ("NBAC") to examine the many ethical issues related to human subjects research, and in one of its several reports the Commission explicitly called for enhanced institutional management of institutional, IRB, and individual fCOIs. ${ }^{20}$

Adding to the turmoil of the late 1990 s and early 2000 s, the heretofore low-key OPRR became unusually and publicly active by suspending human subjects research, seriatim, in more than a dozen major research universities for largely technical violations of Informed Consent and IRB procedures. One suspension, at the University of Colorado, lasted nine months. Another, at Duke University, sparked a Time Magazine cover showing a human research subject cowering in a rodent cage under the banner: How Medical Testing Has Turned Millions of Us Into Human Guinea Pigs. ${ }^{21}$ Widespread publicity intensified public and congressional attention to problems in universities' oversight of human subjects research. Then, between 1998 and 2001, three research subjects died, respectively, at the University of Rochester, the University of Pennsylvania, and then, Johns Hopkins University. ${ }^{22}$ Of these deaths, one in particular ${ }^{23}$ attracted extraordinary notice and congressional interest: that at the University of Pennsylvania of a teenager

20. See 1 NATIONAL BIOETHICS AdVISORY COMMISSION, RESEARCH INVOLVING HUMAN Biological Materials: Ethical Issues aND Policy Guidance: Report aND RECOMMENDATIONS (1999), available at $\mathrm{http}$ //bioethics.georgetown.edu/nbac/hbm.pdf; see also 2 NATIONAL BIOETHICS ADVISORY COMMISSION, RESEARCH INVOLVING HUMAN Biological Materials: Ethical Issues and Policy Guidance: Commissioned Papers (2000), available at $\mathrm{http} / / / \mathrm{bioethics.georgetown.edu/nbac/hbmII.pdf.}$

21. Michael D. Lemonick \& Andrew Goldstein, At Your Own Risk, TiME, Apr. 22, 2002, available at http://www.time.com/time/magazine/0,9263,7601020422,00.html (displaying cover of magazine issue).

22. Vera Hassner Sharav, Human Experiments: A Chronology of Human Research, ALLIANCE FOR HUMAN RESEARCH PROTECTION, http://www.ahrp.org/history/chronology.php (last visited Feb. 2, 2011).

23. See id:; Gene Therapy: Is There Oversight for Patient Safety?, Before the S. Comm. on Health, Education, Labor and Pensions, Subcomm. on Pub. Health, 106 Cong. (2000) (statement of Amy Patterson, M.D., Dir. of the Off. of Biotechnology Activities at the Nat'l Inst. of Health) available at http://www.hhs.gov/asl/testify/t000202c.html; see also Bioethics: Gene Therapy Business: The Tragic Case of Jesse Gelsinger, News WeEkLY, Aug. 12, 2000, available at http://www.newsweekly.com.au/articles/2000aug12_bio.html. 
named Jesse Gelsinger, who was participating in an early-phase gene therapy trial that had received all necessary university approvals, as well as approval by the FDA for use of the Investigational New Drug. But examinations ex post revealed that the research team had both taken and not taken actions in violation of FDA requirements, and determined the presence of both individual and institutional fCOIs. It is important to note that extensive investigations of Gelsinger's death by the FDA and by the University, which convened a high-level commission of outside experts to review the facts of the case, never established any direct linkage of the fCOIs to this tragedy. Nevertheless, in the perfervid atmosphere of the late 1990s, the association was enough to stimulate heated calls for congressional and administrative action to strengthen oversight of human subjects research.

\section{THE ACADEMIC COMMUNITY RESPONDS}

\section{A. Accreditation Program for Human Research}

During the later 1990s, professional organizations representing the leadership of universities and academic medicine became understandably concerned about the furor over human subjects research, especially after the Gelsinger tragedy, and the possible harmful effects of new legislation or regulation enacted in such a frenzied and emotional climate. The governing Board of the nonprofit professional development organization Public Responsibility in Medicine and Research ("PRIM\&R"), dedicated to promoting ethical behaviors in human and animal research, had begun to deliberate the wisdom and realism of establishing a de novo accrediting body for human research protection programs. ${ }^{24}$ I became aware of PRIM\&R's deliberations while serving (1997-2008) as Senior Vice President for Biomedical and Health Sciences Research at the nonprofit Association of American Medical Colleges ("AAMC") in Washington, DC, and initially rejected the idea as wishful. All academic institutions, but especially medical schools and teaching hospitals, undergo a variety of recurrent, separate accreditation visits and generally find them very burdensome and expensive, and of uneven value. But as the clamor continued to intensify, I became convinced that the idea of creating an independent entity to accredit academic human research protection programs had merit and could be a very powerful way for the academic community to demonstrate its respect for the public concerns, as well as its own concerns and resolution to correct its perceived shortcomings. With approval from the AAMC leadership and governance and full cooperation from PRIM\&R, I succeeded during the next eighteen

24. Mission, Values, \& Vision, PRIM\&R, PUBLIC RESPONSIBILITY IN MEDICINE AND RESEARCH, http://www.primr.org/AboutUs.aspx?id=4463\&ekmensel=c580fa7b_68_0_4463_1 (last visited Jan. 23, 2011). 
to twenty months in enlisting the participation of five additional leading nonprofit organizations that represented the major private and public university presidents and senior administrators, the life sciences and social and behavioral sciences faculties, and a politically influential umbrella organization whose membership includes all of the patient disease advocacy groups and much of the medical vendor industry. These recruits were: the Association of American Universities ("AAU"), the National Association of State Universities and Land Grant Colleges ("NASULGC"), the Council on Government Relations ("COGR"), the Federation of Societies for Experimental Biology ("FASEB"), the Consortium of Social Science Organizations ("COSSA"), and the National Health Council ("NHC"), all of whom agreed to support the concept and contribute to the start-up capital needed to launch the venture. Importantly, the pharmaceutical industry's DC-based lobbying organization ("PhRMA") was also fully supportive of the initiative and agreed to match the AAMC's share of the working capital, but PhRMA's leadership decided, wisely, it was best that it not be involved or publicly associated with the new organization. With this broad base of support, the Association for the Accreditation of Human Research Protection Programs ("AAHRPP") opened its doors in the fall of 2001, with the seven founding organizations serving as trustees, but with an impregnable firewall between them and the operations of the new entity, which were overseen by its Executive Director and an independent Board of Directors. After a difficult beginning, in large part due to the academy's aversion to accreditation as well as a muting of public concerns, AAHRPP has become a gratifying success, winning plaudits from both Congress and the Administration; at the time of this writing, nearly 1,100 entities - universities, teaching hospitals, VA hospitals, community hospitals, independent IRBs and Clinical Research Organizations ("CROs"), a major pharmaceutical company, and a growing number of academic institutions in Asia and Europe - have been accredited, ${ }^{25}$ and institutions' attention to and, importantly, their investments in their human research protection programs have increased substantially. Human research protection programs in academia and many in the private sector are far more robust, better supported, and deservedly more credible today than they were a decade ago.

\section{B. AAMC Task Force on Clinical Research}

In the fall of 1999 the AAMC leadership decided to form what was to become its first Task Force on Financial Conflicts of Interest in Clinical Research, which fell under the purview of my team and held its first meet-

25. Press Release, Ass'n for the Accreditation of Human Research Protection Programs, Inc., AAHRPP has accredited 223 (Dec. 16, 2010), available at http://www.aahrpp .org/www.aspx?PageID=383. 
ing in the spring, 2000. The Task Force had a roster of twenty-eight members representing academic medicine, the biopharmaceutical industries, bioethicists, university general counsels, the presidents of three major disease advocacy organizations, distinguished journalists no longer engaged in reporting, and a newly retired Congressman who had chaired the NIH Appropriations Subcommittee of the House Energy and Commerce Committee. The Committee was chaired by William Danforth, MD, who had a long and distinguished career as Vice-Chancellor of the Washington University in St. Louis ("WUSTL") Academic Medical Center, then Chancellor and finally Chairman of the Board of WUSTL. ${ }^{26}$ The Task Force was to work for more than eighteen months and produced two reports: the first, in December 2001, addressed individual fCOIs, while the second, in October 2002, addressed Institutional fCOIs. ${ }^{27}$

I digress to make an important point, to which I shall return later in this manuscript when I address what I have called the "challenge of public expectations" medicine. As noted, seven members of the Task Force were not associated with universities or academic medical institutions, or with industry, and at the first meeting of the Task Force it became surprisingly clear how little our "civilian members" understood of the processes required in our socioeconomic system to bring a scientific discovery to pubic benefit. Especially surprising were the disease advocacy leaders, who devote their lives to advocating for more money for $\mathrm{NIH}$ research on the diseases of interest to their members (e.g., cancer, mental illness, AIDS, etc.). They seemed not to understand that with the notable exception of the Department of Defense, the federal government funds research but not development, which is the

26. About WUSTL: Facts, History and Traditions: William H. Danforth, WASHINGTON UNIVERSITY IN ST. LOUIS, http://www.wustl.edu/about/facts/chancellors/danforth.html (last visited Jan. 23, 2011).

27. See 1 Ass'n of American Medical Colleges, Task Force on Financial Conflicts of Interest in Clinical Research, Protecting Subjects, Preserving Trust, Promoting Progress: Policy and Guidelines for the Oversight of Individual FINANCIAL INTERESTS IN HUMAN SUBJECTS RESEARCH (2001), available at https://www.aamc .org/download/75302/data/firstreport.pdf; 2 Ass'N OF AMERICAN MEDICAL COLLEGES, TASK ForCE on Financial CONFLICTS OF INTEREST IN CliniCAL RESEARCH II: PRINCIPLES AND RECOMMENDATIONS FOR OVERSIGHT OF AN INSTITUTION'S FINANCIAL INTERESTS IN HUMAN SUBJECTS RESEARCH (2002), available at https://services.aamc.org/publications/showfile.cfm ?file=version24.pdf\&prd_id=106\&prv_id=117\&pdf_id=24. Because the AAMC's provenance is limited to academic medicine, and to avoid political friction with national organizations that represent university presidents, we limited the scope of these and following reports, directed to AAMC members - medical schools, teaching hospitals, and their faculty members, by focusing them on human subjects research, even though such research takes place elsewhere in a university, for example, in the social and behavioral sciences. Notwithstanding, the reports and their major recommendations, with few technical exceptions, are equally applicable to all academic research and scholarship.

28. See David Korn, The Challenge of Public Expectations, BOSTON REVIEW (May/June 2010), http://bostonreview.net/BR35.3/korn.php. 
province of the private sector, and that to develop tangible public benefits from scientific discoveries requires that there be an "active interface" between scientists and their institutions with private sector agents. Once these members accepted the need for the interface, however, they still could not understand "why money has to change hands," arguing that faculty are well paid and engage in professions that bring them great satisfaction and pleasure. Other committee members reminded that we are a capitalist economy and discussed the requirements of the Bayh-Dole Act, ${ }^{29}$ the expectations of venture capitalists, and the fact that many faculty inventions are far upstream and absolutely require the inventors' continued engagement to move them into the developmental pathway, but I was never certain that we fully convinced our doubters.

The first Task Force report proved to be extraordinarily influential and has guided the development of individual fCOI policies in many of our nation's medical schools and major teaching hospitals. The report established as its core principles that faculty members must disclose to their institution their related fCOIs; that institutions must ensure a high standard of review of these disclosures; and the rebuttable presumption that a faculty member with a related financial interest deemed to be "significant" and to create a fCOI should not be permitted to perform research on human subjects. ${ }^{30}$ This presumption, however, was not an absolute prohibition and could be challenged by the faculty member's demonstration of "compelling circumstances." 31 Although the Task Force did not try to craft a definition of "compelling circumstances," it intended that they be evaluated by considering the nature, magnitude, and "relatedness" to the research of the financial interest, and the degree of risk raised by the interest to the wellbeing of human subjects and the integrity of the proposed research. ${ }^{32}$ It is my personal view that circumstances should be judged "compelling" only if the research could not otherwise be conducted as safely and effectively. Rigorously applied, this would be a very high standard indeed that would permit relatively few challenges to prevail. The approach recommended by the Task Force was intended not to be formulaic and built around "red lines," but rather to require institutions to perform stringent risk-benefit assessments, much like those routinely performed by an IRB. ${ }^{33}$ However, some institutions have concluded that this approach would be too burdensome and expensive and have chosen to default to less administratively onerous approaches structured around absolute prohibitions.

The Task Force's second report addressed for the first time the prob-

29. Government Patent Policy Act of 1980, Pub. L. No. 96-517, 94 Stat. 3015 (Dec. $12,1980)$.

30. See 1 Ass'N OF AMERICAN MEDICAL CollegES, supra note 27.

31. Id at 7 .

32. Id.

33. See generally, id. 
lem of institutional fCOIs in human research. ${ }^{34}$ In contrast to individual fCOIs, with which the academic community had had more than a decade of experience, the first publication in a major professional journal to address institutional fCOI, of which I am aware, appeared in the New England Journal of Medicine in 1994. ${ }^{35}$ The committee was aware that they were stepping onto unplowed ground without guiding precedents, and so it is that the title of the first report chose "Policy and Guidelines for Oversight ..." while the second was framed more cautiously as "Principles and Recommendations for Oversight ....,36

The Task Force report proffered a definition of the problem: an institutional fCOI exists whenever the financial interests of the institution, or of an institutional official or committee, create a risk of unduly influencing institutional processes for the review, conduct, or oversight of [human subjects] research. ${ }^{37}$ The Task Force articulated as a core management principle that institutional administrative functions and responsibilities related to the oversight of [human subjects] research should be cleanly separated from those related to financial and investment management and technology licensing, and then proceeded to build the institutional report around the basic administrative structures and processes articulated in the individual policy, including the "rebuttable presumption," simply increasing the threshold amounts of income or investment that would be deemed to be "significant." This report has had utility in guiding institutional fCOI policies in academic medical institutions, but aside from separation of their financial and academic administrative oversight structures, the report's recommendations have been widely shunned by university presidents as too unwieldy and intrusive. It is my personal opinion, nearly a decade later, that the recommended approach could only be feasible in institutions in which the prevalence of institutional fCOIs was low. But in today's major research universities and academic medical centers, with their robust and aggressive technology transfer programs and pursuit of research partnerships with industry, the prevalence of such potentially conflicting institutional financial interests is no longer low.

I earlier described the Federal-Academic Research Partnership, the delegation of oversight of the conduct of research to the universities, and the "assurance mechanism." Clearly, that partnership was based on trust that the universities would discharge their oversight responsibilities dispassionately and without conflicts, and that trust was tested during the late

34. See 2 Ass'N OF AMERICAN MEdiCAL Colleges, supra note 27.

35. Ezekiel J. Emanual \& Daniel Steiner, Sounding Board: Institutional Conflict of Interest, 332 N. ENG. J. MED. 262, 262-67 (1995).

36. 1 ASS'N OF AMERICAN MEDICAL COLLEGES, supra note $27 ; 2$ Ass'N OF AMERICAN MEDICAL COLLEGES, supra note 27.

37. 2 ASs'N OF AMERICAN MEDICAL Colleges, supra note 27, at 2-3. I have inserted the brackets to emphasize that the definition is applicable to all academic research. 
1990s when the issue of institutional fCOIs first surfaced as a matter of concern in human subjects research. But the credibility of universities as socially privileged institutions of public trust and the integrity of university research is certainly not limited to research involving human subjects. It is worth recalling here an inspiring articulation of the crucial role of universities in society that I first cited in my aforementioned Journal of the American Medical Association ("JAMA") Commentary a decade ago, the origin of which is unknown:

All true universities, whether public or private, are public trusts designed to advance knowledge by safeguarding the free inquiry of impartial teachers and scholars. Their independence is essential because the university provides knowledge not only to its students, but also to the public agency in need of expert guidance and the general society in need of greater knowledge; and ... these latter clients have a stake in disinterested professional opinion, stated without fear or favor, which the institution is morally required to respect. $^{38}$

Institutional fCOI remains a critically important challenge, at the heart of the "Federal- Academic Research Partnership," to which neither the university community, the federal government, nor the public has yet come to terms. 39

38. David Korn, Commentary, Conflicts of Interest in Biomedical Research, 284 JAMA 2234, 2234 (2000). In my JAMA Commentary, I attributed this language to the "Declaration of Principles" issued by the Association of American University Professors in 1915 , when the challenges had to do with tenure, not fCOIs. Such was the citation that accompanied this language when I first encountered it in a published article that I can no longer remember. I only recently learned from the AAUP that the attribution is incorrect, so the source is now unknown. I would be proud to claim authorship because I wholeheartedly agree with the rhetoric.

39. In January 2011, the DHHS Office of the Inspector General ("OIG") issued its first report entitled Institutional Conflicts of Interest at NIH Grantees. The study was a survey of 250 awardee institutions, asking whether they had any policies and procedures addressing institutional financial interests and conflicts of interest. Only 156 institutions replied, of which seventy responded positively, and of these only fifty-nine had written Policies and Procedures ("P\&Ps"). Twenty-one institutions' P\&Ps had written definitions of Institutional financial interests, and of these eighteen also had written definitions of an Institutional Financial Conflict of Interest ("IfCOI"). The definitions were variable, with the most common elements being institutional equity in private and/or public entities, financial holdings of institutional officials overseeing research (including members of research oversight committees), institutional royalties flowing from intellectual property, and gifts to the institution from research sponsors. See OfF. OF THE INSPECTOR GEN., DEP'T OF HEALTH AND HUMAN SERV., OEI-03-09-00480, INSTITUTIONAL CONFLICTS OF INTEREST AT NIH GRANTEES (2011), available at http://oig.hhs.gov/oei/reports/oei-03-09-00480.pdf. The most common management strategy, as recommended in the AAMC report, was separation of the administra- 


\section{FINANCIAL CONFLICTS OF INTEREST, WHERE THEY WENT}

During this first decade of the 21 st Century, Congress, the major media, and the general public have become much more aware and much less tolerant of fCOIs in individuals, organizations, and professions that assert or are generally presumed to have fiduciary responsibilities. With respect to universities, academic medical institutions, and the medical profession and its vendors, bitingly critical books have been published, such as: The Truth About Drug Companies: How They Deceive Us and What to Do About It ${ }^{40}$ by Marcia Angell; On the Take: How Medicine's Complicity With Big Business Can Endanger Your Health, ${ }^{41}$ by Jerome Kassirer; University, Inc: The Corporate Corruption of Higher Education, ${ }^{42}$ by Jennifer Washburn; and Universities In The Marketplace, ${ }^{43}$ by Derek Bok. The collapse of the "high tech bubble" at the turn of the century, and the collapse of Enron, WorldCom, etc., wiped out jobs and pensions and exposed the corruption of the accounting profession, which had learned that cultivating large consulting practices with their clients was ever so much more lucrative than auditing them. Then, slightly more than half a decade later, the Great Recession, which nearly brought down the world's financial systems, was the price paid by the public for rampant self-dealing and betrayal of fiduciary obligations in the world of high-finance, bond ratings, and mortgage lending and securitization.

In the middle of this decade, Eliot Spitzer, then the Attorney General of New York, filed a criminal fraud complaint against the international pharmaceutical powerhouse, GlaxoSmithKline ("GSK"), and several of its smaller company partners for systematically suppressing the results of negative clinical trials designed to evaluate the safety and efficacy of antidepressant medications in children and teenagers, populations in which the therapeutics had never been tested but were being heavily marketed. ${ }^{44}$ That the pharmaceutical industry did such things as part of their marketing strategies was not really unexpected, but the filing of the criminal complaint most certainly captured the attention of the industry, the medical profession,

tive oversight of research from financial management, and the most common "remedy" was disclosure. The report strongly recommended that NIH regulate IfCOIs, and NIH, in its response, demurred, writing "institutional conflict of interest is a highly complex issue . . . . Therefore, we will take the OIG's recommendation into consideration as we consider future actions on extramural financial conflict of interest." Id. at 24.

40. Marcia Angell, The Truth About the Drug Companies: How They Deceive US AND WHAT TO DO ABOUT IT (2004).

41. JEROME KasSirer, ON THE TAKE: How MEDICINE'S CoMplicity With Big BUSINESS CAN ENDANGER YOUR HEALTH (2005).

42. JENNIFER WASHBURN, UNIVERSITY, INC: THE CORPORATE CORRUPTION OF HIGHER EDUCATION, (2005).

43. DeREK BOK, Universities IN THE MaRketPlace: The CoMmercialization of HighER EDUCATION (2003).

44. See Complaint, New York v. GlaxoSmithKline, No. 04-CV-5304 (N.Y. Sup. Ct. June 2, 2004). 
and the public. The complaint was ultimately settled for hundreds of millions of dollars, and as part of the settlement the companies were forced to pledge going forward that they would post on their publicly accessible websites all of the clinical trials they sponsored, without exception. By doing so, scholars would be able to identify trials that would never appear in the literature, and the FDA, trials that, illegally, had not been reported in new drug registration or new drug indication packets submitted by the manufacturers for agency approval. This was the first time such a demand had been imposed on the industry, and in its aftermath, many of the industry's leading companies, as well as its DC-based lobbying organization, PhRMA, decided to do the same, beginning a long-overdue and most welcome process of industry transparency that would only increase in subsequent years. Spitzer did not limit his prosecutorial zeal to the pharmaceutical industry, but then turned his attention seriatim to the several sectors of the financial services industry, in most instances successfully winning large punitive financial settlements of charges of betrayal of fiduciary responsibilities, as well as commitments to substantial changes in long-established industry behaviors and practices.

Spitzer was succeeded as Attorney General by Andrew Cuomo, who turned his attention to financial self-dealing by universities in their Student Loan and Overseas Studies programs, respectively. With respect to the former, Cuomo illuminated the widespread university practice of promoting to their students one or more favored lenders, from which the institution would receive guaranteed financial kickbacks. In the Overseas Studies Programs, institutional officials were selecting contractors in part on vendors' willingness to provide financial kickbacks directly to them. In both instances, Cuomo filed class-action complaints naming many universities, and the resulting settlements forced changes in administrative behaviors and the cessation of kickbacks. Neither of these well-publicized episodes brought favor to the universities or sincerity to their pledges always to put the interests of their students first and foremost.

The events recited here, and perhaps especially the pioneering prosecutorial work of AG Spitzer, greatly raised public awareness of the damages and suffering that can be caused by covert financial COIs. Let me offer two brief illustrative examples. The first is from an article in the Washington Post on January 6, 2008: "The Financial Planning Association . . . . sued over whether brokers could call themselves investment advisors . . . . [a] federal appeals court in DC said no. A stockbroker is a salesperson, not an advisor."45 The second is from the New York Times on November 21, 2009 and cites from the criminal complaint filed by the State of Ohio against Moody's, Standard and Poor's, and Fitch, the "Big-3" bond rating agencies:

45. Jane Bryant Quinn, Split of Brokers and Advisers Forces Customers to Choose, WASH. Post, Jan. 6, 2008, at F1. 
"We believe that the credit rating agencies, in exchange for fees, departed from their objective, neutral role as arbiters ... [and sold their integrity] ... to the highest bidder." ${ }^{, 46}$ Rating agencies are paid by the issuers of the securities they are hired to rate and do not receive their full fees unless the requested rating is provided. ${ }^{47}$ Such is the assurance system on which the financial markets and countless investors depend for independent, credible valuation of marketed securities! The failure of the bond rating companies is sadly reminiscent of the collapse of the accounting industry a decade earlier.

\section{ENTER THE NATIONAL INSTITUTES OF HEALTH (NIH) AND THE DHHS OIG}

The year 2004-2005 can aptly be called NIH's annus horribilis, a year of great embarrassment and punitive fCOI regulations. The NIH is a federal agency nested formally within the PHS within the DHHS. As such, the agency might be expected to conform to the stringent fCOI regulations that apply to all federal employees. However, in the mid-1990s then Director Harold Varmus won significant relaxation of these rules, primarily on the ground that it would facilitate his ability to recruit and retain top-level basic and, especially, clinical investigators from academia. University faculty salaries had begun to escalate sharply, especially in medicine and the biomedical sciences, and additionally, faculty generally enjoyed a "one-day a week" consulting privilege that enabled them to interact with the private sector and receive handsome fees. The federal government had in prior years partially relaxed compensation limits, especially for federal physicians and physician scientists, but Varmus argued persuasively that relaxing the federal fCOI regulations to permit freer consultative activities for fulltime NIH scientists would significantly facilitate NIH's efforts in recruitment and retention of "stars." The modified regulation established an fCOI oversight process within the Office of the NIH Director and imposed appropriate boundaries on the relaxed consulting privilege. The key feature of the oversight system was disclosure and prior approval.

In December 2003, the Los Angeles Times published the first in a series of articles by investigative reporter, David Willman, ${ }^{48}$ naming senior NIH scientists and accusing them of major violations of the agency's relaxed fCOI rules. Some of the behaviors described were indeed distressing - and would have been equally so for academics, and the articles implied that such violations might be widespread among the NIH's senior physi-

46. David Segal, Ohio Sues Rating Firms For Losses In Funds, N.Y. TIMEs, Nov. 21, 2009 , at B1.

47. See id.

48. David Willman, Stealth Merger: Drug Companies and Government Medical Research, Los ANGELES TIMES, Dec. 7, 2003, at A1. 
cian-scientist corps. ${ }^{49}$ The NIH began an intense review of its fCOI records, and the Congressional Oversight Committees scheduled hearings; allegations were freely being thrown about, Congress was furious, the DHHS was embarrassed and angry, and, in truth, no one at that instant knew how widespread these violations might be; the NIH's oversight system seemed to have broken down. To try to limit the damage and regain the initiative, the US Office of Government Ethics either decided or was ordered to tighten the NIH fCOI rules significantly. The revised and truly draconian regulations ${ }^{50}$ were imposed upon the NIH and took effect immediately: they essentially forbade NIH scientists and staff from any consulting interactions with or financial holdings in organizations with which the agency interacted in any way ("Substantially Affected Organizations ("SAOs")"). It was not even clear at the time whether NIH scientists could give lectures at universities or academic medical institutions that received NIH grants (SAOs), or serve as officers in their professional societies or on the editorial boards of their professional journals. In the end, the total numbers of wrongdoers identified within NIH's ranks proved to but a relative handful, and about a year later, the draconian regulation was partially relaxed, although compensated consulting relationships between SAOs and the NIH leadership, officials in the agency's Extramural Programs, and NIH scientists who conduct research on human subjects, the primary recruitment and retention targets of Varmus' relaxation, remain largely prohibited to this time.

When the NIH furor was at its height, key congressional leaders wrote to then NIH Director Elias Zerhouni to ask, if the new fCOI regulation was good for the intramural NIH scientists, why would it not be good as well for all the extramural scientists whose research programs and facilities consumed more than eighty percent of the NIH's annual appropriation in the form of sundry varieties of Research Project Grants? Publication of this inquiry sent tremors through the research universities and academic biomedicine. At about that time, two events occurred that are important to this narrative:

1. The DHHS OIG deployed personnel to the NIH campus to keep a close eye not only on NIH's internal fCOI management but also on the agency's discharge of its oversight responsibilities for the extramural community under the 1995 fCOI regulation. The OIG contingent settled into the NIH campus, comfortably it would seem, since they remain there to this time.

2. In September 2005, a small group of leaders from the AAU and

49. See id.

50. See Supplemental Standards of Ethical Conduct and Financial Disclosure Requirements for Employees of the Department of Health and Human Services, 70 Fed. Reg. 5543 (interim final rule with request for comment), available at http://www.gpo.gov/fdsys/ pkg/FR-2005-02-03/pdf/05-2029.pdf. 


\begin{abstract}
AAMC constituencies, which included me, convened in DC to consider an appropriate response from the university and academic medical communities to the troubling events occurring at the $\mathrm{NIH}$, the public anger provoked, and the interest of key Congresspersons to extend the NIH's punitive fCOI rule to the extramural community. The group agreed that research universities and academic medical centers exist in a "concatenated chain of trust and interdependence," such that regulatory lapses by any one member can bring retribution to the entire community in the form of new law or regulation, and they identified as one key issue of concern a lack of consistency in fCOI policies and practices across our member institutions. A second key concern was, and remains, the problem of "clashing mixed messages," or what I have dubbed the "conflict of public expectations," that is, that academia must be ever more vigorous in promoting technology transfer and partnering with the private sector while remaining pristine and untarnished by any appearance of fCOI. Because inconsistency in fCOI policies and practices posed a danger to all, the group urged the AAMC and AAU to combine their efforts and establish a new initiative aimed at promoting greater consistency in $\mathrm{fCOI}$ practices across the academic community. I shall return to this initiative shortly.
\end{abstract}

\title{
VII. THE ACADEMIC COMMUNITY SHOOTS ITSELF IN THE FOOT
}

Perhaps of its own volition, perhaps because the OIG was breathing down its neck, the NIH decided to conduct Targeted Site Reviews ("TSRs") at eighteen public and private awardee institutions to examine how well they were complying with their obligations under the fCOI Regulation. The final report, which the NIH decided to post quietly on its website ${ }^{51}$ without any publicity, lavishly praised the seriousness and diligence the targeted institutions were demonstrating in trying to comply with the fCOI Rule. ${ }^{52}$ However, they did report three areas of concern:

1. The institutions were using too narrow a definition of "investigator" with respect to who on a research team must disclose related financial interests. ${ }^{53}$ [The Rule addresses this point clearly.]

51. See Notice, National Institutes of Health, Observations from NIH's Targeted Site Reviews on Financial Conflict of Interest (Feb. 16, 2007), available at http:/grants.nih.gov/ grants/guide/notice-files/not-od-07-048.html.

52. See National Institutes of Health, TaRgeted Site ReViews on Financial CONFLICT OF INTEREST OBSERVATIONS (2007), available at http://grants.nih.gov/grants/policy /coi/TSR Observations 2-14-2007.doc.

53. Id. at 2 . 
2. The institutions were not diligently exercising their obligation to report to NIH every instance in which they had detected and dealt with an fCOI in a federal grant recipient. ${ }^{54}$ Some institutions had simply "forgotten," for months at a time. [I earlier called attention to the simplicity of this requirement as evidence of the light-handedness of the Rule.]

3. The institutions were not satisfactorily discharging their obligation to monitor subrecipients participating in the funded research. $^{55}$ [This issue is admittedly challenging because the institutions have no formal oversight authority of their research project subrecipients.]

In spite of the NIH's effort to downplay its report, the posting was noted by the OIG, which launched a formal investigation of NIH's oversight of the 1995 Rule. $^{56}$ The OIG Report was sharply critical of the NIH's stewardship, and much of its report focused on that. For example, it found that the agency had no idea how many fCOI reports had been submitted by awardee institutions in past years, partly because each NIH institute was collecting reports from its own awardees on paper, and those reports could not be found, and partly because NIH's requirement that all reports to the institutes be shared with the Office of the Director ("OD") had been widely ignored for more than a decade. ${ }^{57}$ In any event, the OD had no central file; ${ }^{58}$ worse yet, it had no idea how many fCOI reports, required under the Rule, the NIH had received. ${ }^{59}$ The OIG issued three recommendations, two of them directed at the NIH, viz., that NIH greatly increase its efforts to assure intra-agency compliance, and that the OD rapidly establish a central electronic record system for awardees' fCOI reports. ${ }^{60}$ The third recommendation, unexpectedly, turned away from the NIH and toward the awardee community and asserted that the institutions should be required to disclose to the NIH all potential fCOIs they detect, and that the NIH should examine the details of the institutions' reviews, decisions, and mitigation processes. $^{61}$

This last recommendation stunned the academic community because it called for fundamental change in the interpretation and implementation of the 1995 Rule, and much more intrusive NIH participation in what had been exclusively the prerogative of the institutions: to evaluate their faculty in-

54. Id.

55. Id.

56. See Off. Of THE INSPeCtor Gen., Dep'T Of HeAlth and Human SeRV., OEI-0306-00460, NAT'L INST. OF HEALTH: CONFLICTS OF INTEREST IN EXTRAMURAL RESEARCH (2008), http://oig.hhs.gov/oei/reports/oei-03-06-00460.pdf.

57. Id. at 5.

58. Id. at 9.

59. Id.

60. Id. at 16 .

61. Id. at 17 . 
vestigators' disclosures and make what must be ultimately judgment calls about the existence of a fCOI and its magnitude, severity, relatedness to the research project, and ultimately, its disposition. Although NIH's response made clear that it had neither the interest nor the capability to manage such a workload, it nonetheless soon after (February 2008) requested for the first time from nineteen awardee institutions detailed information about fCOIs, about which the institutions had dutifully notified the agency. The OIG had showed its hand, and it was not to be for the last time.

\section{NEW ACTORS ENTER THE FCOI MIX}

The NIH's TSRs attracted a new source of attention, from Senators Charles Grassley, the then Ranking Member of the Senate Finance Committee, and Herb Kohl, the then Chairman of the Senate Ageing Committee. Both Committees have keen interest in the Medicare program and its costs, and the Senators were concerned that fCOIs could bias clinical research in favor of new and expensive therapeutics produced by the sponsoring companies. Also troubling were the promotional talks extolling new drugs and devices, delivered to physician audiences by influential academic specialists who neglected to disclose that they were being compensated handsomely for these talks by the products' manufacturers. Both Senators turned their attention to fCOIs in academic medicine. Grassley began by requesting information from NIH about the responses to the TSRs NIH had received from the visited institutions. At about the same time, Congressmen John Dingle and Bart Stupak, members of the Oversight and Investigations Subcommittee of the House Energy and Commerce Committee, sent a letter to the Director of the National Cancer Institute ("NCl") seeking information about a large NCI-sponsored clinical trial designed to evaluate the effectiveness of Computed Tomography ("CT") chest scans in detecting small and putatively operable neoplasms in the lungs. There was considerable debate within the medical profession, and concern in Medicare, not only about the medical effectiveness but also the cost-effectiveness of such a very expensive diagnostic screening technology. But the trial became the center of even more controversy when it was learned that the lead CoPrincipal Investigator ("PI"), a professor of radiology at the Cornell-Weil Medical School, and at least one other key participant, had nearly a dozen patents filed on key aspects of the screening technology being used, the value of which would soar if the technology became accepted for broad population screening. Unfortunately, the Co-PI had failed to notify the NCI about her patents when she was being chosen to lead the study, and further inquiry revealed that she had often "forgotten" to mention the patents in manuscripts she submitted to journals for publication.

A new actor, then New Jersey Attorney General Christopher Christie, also concerned about the medical profession's increasingly cozy financial relationships with its vendor industries and their effects on the costs of 
health care, subpoenaed records of payments to orthopedists from the five largest manufacturers of orthopedic devices, declaring these to be illegal kickbacks. The manufacturers fairly quickly agreed to settle a civil complaint for multi-hundreds of million dollars (aggregate) in penalties and further agreed to post all such payments henceforth on their company websites where they would be visible to the public. This was the first time that vendors of health products had been forced to reveal to the public their covert payments to physician or surgeon customers. The settlement attracted Senator Grassley, who joined with AG Christie to turn the spotlight onto the orthopedists receiving these payments, most of whom, not surprisingly, were recognized leaders in academic medicine. Among other queries, the investigators asked whether the surgeons had disclosed their payments to their patients and to their academic institutions. Grassley and Kohl then greatly intensified the inquiry by demanding from pharmaceutical and medical device manufacturers a full accounting of their payments to a named group of academic physician leaders during the prior seven years. The physicians were culled from Psychiatry, Orthopedics and Cardiology and were known to the vendor companies as "Key Opinion Leaders," ("KOLs"), because of their professional eminence and influence in their specialties. The Senators then requested from the physicians' academic institutions records of the vendor payments the doctors had disclosed to them. For a variety of reasons that included differences in accounting periods, or inclusion of expense reimbursements in vendors' tallies of payments, as well as failure of the physicians to report these payments fully and accurately, or at all, there inevitably were discrepancies, some modest, more of them large, some very large. Finally, Senator Grassley sent formal letters to the target physician(s), his or her hospital president, and often his or her university president, charging failures of the named physicians and surgeons, fully and accurately to report their vendor payments from named companies, and failure of the institutional systems for capturing these payments to detect non-compliance. The Senator rolled out his charges seriatim, in each instance first reading his indictment into the Congressional Record before releasing the story to a favored New York Times or Wall Street Journal reporter. Grassley's revelations received blaring front-page publicity and roiled the involved institutions as well as the accused physicians, and disciplinary proceedings ensued for violations of institutional disclosure policies.

Whatever other motivations Senator Grassley may have had, he accomplished his major objective of demonstrating the frailty and failings of institutions' fCOI policies and processes based entirely on faculty members' disclosures of financial interests that they alone determine should be disclosed, and which lack capability to verify completeness and accuracy. By doing so, the Senator added fuel to the fire that the OIG had already ig- 
nited within the NIH. But for academic medicine a partial remedy looms in the recently enacted Health Care Reform Act, ${ }^{62}$ which contains within its voluminous pages the entire Grassley-Kohl Sunshine Act, ${ }^{63}$ which mandates annual reporting by vendors of all of their payments above a de minimis to physicians and health care institutions. ${ }^{64}$ These payments are to be organized and displayed in a publicly accessible register, one may only hope in a standardized and useful manner, on a website to be created by the DHHS. ${ }^{65}$ The system is to become operative in $2013 .^{66}$ In the meantime, many of the major health care vendors have already established company sites on which they are listing quarterly or semi-annually all their payments to physicians. Some of these sites have been created voluntarily; at least eighteen result from costly settlements of criminal complaints of off-label promotion of therapeutics, which have typically been accompanied by Corporate Integrity Agreements; the 2 largest settlements involved Eli Lilly in 2008 for $\$ 1.4 \mathrm{~B}$ and Pfizer in 2009 for $\$ 2.3 \mathrm{~B}^{67}$

Although these actions certainly add welcome and needed transparency to what had been an entirely covert system for influencing physician's therapeutic decisions, it remains to be determined how effective these public disclosures will be in altering public perceptions or physician behaviors. Two recent examples illustrate the challenge. The first is from the trade publication, The Pink Sheet, October 19, 2009. Lilly posted its first quarter payments, and the highest paid was a psychiatrist, who reported that "he was initially concerned that payment databases could be misleading or used to attack a physician's credibility. [He] changed his mind, however, once he told his patients about his work with pharma companies and they responded positively." "68 The second, from the Boston Globe, January 23, 2010, describes a Harvard Medical School faculty physician who resigned his faculty and hospital appointments, the latter at the Brigham and Women's Hospital, to continue his heavy schedule of promotional speeches, for which was being paid handsomely as a contracted participant in a GSK Speakers Bureau. The US director of media relations for Glaxo was "not sure whether [the physician] will be as much in demand as a speaker without the prestigious Brigham and Harvard titles."69

62. Patient Protection and Affordable Care Act, Pub. L. No. 111-148, 124 Stat. 119 (2010).

63. Physician Payments Sunshine Act of 2009, S. 301, 111th Cong. (2009).

64. S. $301 \S 2(a)(1)$.

65. S. $301 \S 2(\mathrm{c})(1)(\mathrm{C})$.

66. Patient Protection and Affordable Care Act, Pub. L. No. 111-148, §6002, 124 Stat. $119,689(2010)$.

67. Aaron Kesselheim, et al., Whistle-Blowers' Experiences in Fraud Litigation against Pharmaceutical Companies, 362 NEw ENG. J. MED. 1832, 1833 (2010).

68. Lilly Outside "Faculty" Is Headed by 22 Physicians Receiving \$50,000 or More, THE PINK SHEET, Oct. 19, 2009, available at http://www.biopharmatoday.com/2009/10/lillyoutside-faculty-is-headed-by-22-physicians-receiving-50000-or-more.html.

69. Liz Kowalczyk, Doctor Quits Brigham to Speak for Pay; Partners has Strict Rules 


\section{AGAIN, THE ACADEMIC COMMUNITY RESPONDS}

A few months following the September 2005 gathering of AAU and AAMC leaders, the associations formed a joint committee, chaired by Mark Wrighton, Chancellor of WUSTL, and comprised of four sitting university Presidents or Chancellors and fifteen leaders from the academic medical community. As with the prior AAMC Task Force, this initiative came under the purview of my AAMC team. The committee, whose report was published in February $2008,{ }^{70}$ was charged to begin with the AAMC's prior reports on individual and institutional fCOIs, define the key issues that needed to be addressed, refine and clarify the prior recommendations, and provide practical guidance to their communities. The committee's report was entitled Protecting Patients, Preserving Integrity, Advancing Health: Accelerating the Implementation of COI Policies in Human Subjects Research. The committee strongly reaffirmed the 2001 and 2002 recommendations with a few modest refinements, stressed the necessity for more consistent policies and practices across academic institutions, and, cognizant of what was happening at the $\mathrm{NIH}$, warned that time was of the essence in fully implementing effective and comprehensive COI policies. ${ }^{71}$ The urgency of this call to action was, in my view, unfortunately somewhat blunted by the committee's need to confine its work to Human Subjects Research. But as before, the AAU had remained adamant in linking its agreement to participate on the committee with retention of the limiting condition.

The Committee's report was entirely heuristic and designed to offer practical guidance. The three chapters addressed, respectively, Individual fCOI, Institutional fCOI, and Implementation of fCOI Policies, and the five Appendices: Model Institutional fCOI Policy; an Analysis Template with ten Exemplary Case Studies; Definition of Financial Interests in Research; Points to Consider; and the Committee Roster. ${ }^{72}$ This report was envisioned to be a "How To Do It Manual," and so it was. For better or worse, it broke little conceptual new ground.

\section{FCOIS IN MEDICAL EDUCATION}

In January 2006 , a paper published in $J A M A^{73}$ by twelve leaders of academic medicine, including the then President of the AAMC, berated the

on Drug-Firm Honoraria, The Boston GLOBE, Jan. 23, 2010, at 1.

70. AAMC-AAU ADVISORY COMMITTEE ON FinANCIAL CONFLICTS OF INTEREST IN Human Subjects Research, Protecting Patients, Preserving Integrity, Advancing Health: Accelerating the Implementation of COI Policies in Human SubJects RESEARCH (2008), available at www.aau.edu/research/Rpt_AAU-AAMC_COI_208.pdf.

71. See id.

72. Id.

73. Troyen A. Brennan et al., Health Industry Practices that Create Conflicts of Interest: A Policy Proposal for Academic Medical Centers, 295 JAMA 429 (2006). 
"entitlement" culture that had become so embedded in the medical profession, under which physicians had become habituated to receiving billions of dollars a year in gifts, meals, paid travels to exotic destinations, etc. from the pharmaceutical and medical device industries, and to a lesser extent, the biotechnology industry. These payments come entirely from the companies' marketing budgets under the umbrella of "medical education" and have been shown repeatedly in proprietary industry studies to be an especially effective mechanism for winning physicians' uptake of new and typically very expensive company products, independent of credible (or any) data demonstrating that those products were as effective or better than comparable therapeutics already on the market, many of which have been thoroughly studied over the years and were especially well understand in diverse practice settings, and many of which have gone off-patent and become generic. The authors declared these payments create fundamental fCOIs with medical professionalism and urged that they be eliminated from the profession, beginning in the academic medical centers, where future generations of physicians are nurtured in the science, art, and professional standards and ethics of medicine. ${ }^{74}$ These unseemly habits and practices increase public suspicion of physicians, their institutions, and their professional organizations, and they undermine confidence in the independence of institutional and individual decision making; the altruism of the physician and the profession; personal and institutional integrity; the trustworthiness of academic medicine across its missions; and the ability and capacity of academic medicine to self-regulate.

Although a few of the nation's leading academic medical centers had already begun in 2005-06 to implement new stringent institutional policies to eliminate or sharply circumscribe these offending practices, the AAMC decided it was appropriate to form a Task Force on Industry Funding of Medical Education ${ }^{75}$ that would include senior officials from the industry as well as from academic medicine with the aim of stimulating a productive dialogue and the hope of reaching some consensus. This initiative once again fell under the direction of my team. The Task Force was chaired by Roy Vagelos, the retired and respected long-time Chairman of Merck, and vice-chaired by William Danforth, who had chaired the AAMC's first Task Force on fCOIs. The roster contained in addition to leaders and faculty from academic medical centers, medical students and residents, bioethicists, members of the public, and four sitting industry CEOs, from Pfizer, Lilly, Amgen and Medtronic, respectively. The Task Force was charged to forge consensus principles to guide medical schools and teaching hospitals in de-

74. Id. at 431.

75. See Association of American MEdical Colleges, Industry Funding of MEDICAL EDUCATION: REPORT OF AN AAMC TASK FORCE (2008), available at https://services.aamc.org/publications/showfile.cfm?file=version114.pdf\&prd_id=232\&prv_ $\mathrm{id}=281 \&$ pdf_id=114. 
veloping policies and procedures for managing various forms of industry support of medical education. The AAMC made clear at the outset its concerns with such industry funding, which included conflict of interest, compromise of objectivity and integrity of professional decision-making, blurring of marketing and scientific evidence, distortions in prescribing and in formulating Practice Guidelines, adverse effects on the "hidden curriculum" for students and trainees, and the growing body of scientific evidence about influence and reciprocity, and the inadequacy of disclosure as a safeguard. ${ }^{76}$ I boldfaced the last because it was the stimulus for me to join with colleagues in organizing a scientific symposium on the topic, which took place a few months after the Task Force was launched, and to which I return below.

Over the course of about fourteen months, the Task Force agreed on the following important, albeit somewhat aspirational, recommendations:

1. Academic medical centers should adopt policies consistent with the Task force Report to support a learning environment that nurtures professionalism. ${ }^{77}$

2. To the extent that certain interactions with industry are prohibited within academic medical centers, they should also be prohibited off-site. ${ }^{78}$

3. Industry should not invite academic medical center personnel to participate in practices off-site that the medical center prohibits on-site. $^{79}$

4. Academic medical centers should expect their off-site teaching and training partners to adhere to the standards of the medical center regarding interactions with industry. ${ }^{80}$

5. Academic medical centers should raise awareness among students and faculty of the challenges to professionalism presented by certain industry interactions.

6. Academic medical centers should ensure opportunities for students to build their critical evaluation skills.

7. Academic medical centers should increase students' understanding of the processes of drug discovery, clinical testing, assessment of drug and device safety, the difference between efficacy and effectiveness, and FDA regulations. ${ }^{83}$

The Task Force also agreed, after much deliberation and debate, that

76. Id. at $1,3-8$.

77. Id. at 26 .

78. Id. at 17 .

79. Id. at 9 .

80. Id. at 10 .

81. Id. at 11 .

82. Id.

83. Id. at 26. 
academic medical institutions should ban all gifts ${ }^{84}$; restrict site access by pharmaceutical and device representatives (aka "salespersons"); ${ }^{85}$ prohibit direct industry funding of Continuing Medical Education; ${ }^{86}$ require industry- sponsored educational grants for students and trainees to be gifts to the medical center and not to individuals; ${ }^{87}$ ban travel funds from industry for merely attending meetings; ${ }^{88}$ and ban ghostwriting and guest authorship. ${ }^{89}$ The Task Force struggled but could not reach consensus on: banning pharmaceutical samples; faculty and student participation in industry-sponsored, non-accredited "educational" programs; and, most contentious of all, faculty participation in industry "Speakers Bureaus." Of the several reports developed at the AAMC under the direction of my team, I am least able to estimate the impact of this report on the academic medical community, although I am confident it has been helpful to them in dealing with these difficult issues in their own institutions and communities. It is very hard to break engrained habits and give up engrained expectations! I know for certain, however, that the participation of the industry CEOs and their top deputies in this often contentious undertaking had a major impact on them: it opened their eyes to the firm resolve of the leadership of academic medicine to eliminate "business as usual" and begin what will be a long and difficult process of eradicating this degrading "culture of entitlement" from the medical profession.

Most of this manuscript has focused on fCOIs in academic biomedical research, and the reader may be puzzled by my introduction of fCOIs in medical education at this point. In part, it was because the narrative has been chronological, and this topic hit the AAMC's radar screen and the profession at this time. But more importantly, the topic does relate directly to my predominant research theme: the "culture of entitlement" has aroused many critics who find the practices just discussed repellent, and in their outrage some of them have taken to demonizing the pharmaceutical industry. In my aforementioned Commentary in the Boston Review I wrote:

Some commentators address these issues by demonizing pharmaceutical and related vendor industries and advocating for marked reduction or even total elimination of interactions between them and academic medicine. Such uncompromising rhetoric has its own adverse consequences ... . I I advocate distinction of those industry relationships that are largely gratuitous,

86. Id. at 19.

87. Id. at 21 .

88. Id. at 22 .

89. Id. 
distracting, self-indulgent, and corrupting, and should be eliminated, from those that have value and serve important public functions. ${ }^{90}$

Primary among the latter are legitimate research relationships, conducted ethically and transparently, between academic medicine and industry that are essential to identify and validate new drug targets and facilitate the reduction of biomedical scientific inventions into tangible public benefits such as new diagnostics, therapeutics, and medical devices. By eliminating the "culture of entitlement" that has become so embedded in medical education and practice, those relationships between academic medicine and industry in research that have integrity and are essential can be strengthened and flourish and they can be evaluated in their own right rather than being smeared and condemned vicariously, as they too often now are.

\section{THE SCIENTIFIC BASIS OF INFLUENCE AND RECIPROCITY: A SYMPOSIUM}

On June 12, 2007, colleagues from the Baylor College of Medicine and I organized a symposium to present the latest scientific insights into Influence and Reciprocity, and we published a monograph summarizing what we had learned. ${ }^{91}$ We chose this topic because exciting new insights are emerging from the neurosciences, behavioral economics and psychology that are directly relevant to COIs. We were fortunate to assemble four of the leading investigators in the field: Read Montague, $\mathrm{PhD}$, then Professor of Neuroscience and Director of the Human Neuroimaging Laboratory, Baylor College of Medicine; Dan Ariely, PhD, then Sloan Professor of Behavioral Economics, MIT Sloan School of Management; George Loewenstein, $\mathrm{PhD}$, Herbert A. Simon Professor of Economics and Psychology, Carnegie Mellon University; and Max Bazerman, PhD, D.Sc. Economics (hon), Jesse Isidor Straus Professor of Business Administration, Harvard Business School. $^{92}$

Montague described the use of fMRI technology in classical behavioral experiments to demonstrate the anatomical correlates of the effects of favors and other forms of influence on persons' choices. ${ }^{93}$ There are specific neural pathways in areas of the brain that lie beneath awareness (neuroscientists avoid the Freudian connotations of "the unconscious") that consistently respond to favors or other acts of kindness, or even the antici-

90. Korn, supra note 28.

91. See Symposium, supra note 4.

92. Space permits only a snapshot of the insights presented, but for those interested, the monograph is freely available online. See generally Symposium, supra note 4.

93. Id. at 9-12. 
pation of such, and that influence our choices and decisions. ${ }^{94}$ There is no reason to doubt that these pathways are functional in all human beings, and there is reason to suggest that they may be of ancient origin and evolved under heavy positive selection. These studies, consistent with prior evidence from psychology, sociology, and behavioral economics, are illuminating the neurological substrates of cognitive behaviors that occur without awareness. Some have dubbed these processes "deliberation beneath awareness" or "deliberation without intention." 95

Ariely summarized a large body of empirical evidence indicating that persons can tolerate a limited amount of dishonest behavior without impairing their self-image or self-worth. ${ }^{96}$ That is, persons' internalized standards of acceptable behaviors seem to permit some bounded "wiggle room" within which limited amounts of dishonest behaviors do not threaten persons' image of self." Importantly, such "limited amounts" are typically less than the maximum that is possible. ${ }^{98}$ In other words, persons seemingly will cheat if given the opportunity, but just a little. "Mindfulness" appears to reduce significantly the amount of dishonest behavior under identical experimental conditions." In one experiment, measurable "mindfulness" was accomplished simply by flashing a copy of the Ten Commandments before the experimental subjects before the "cheating experiment" began. 100

Loewenstein taught that Traditional Economics assumes that professionalism and COIs are asymmetric motives in influencing behavior, and that persons who confront COIs are equipped to recognize and deal with them rationally. ${ }^{101}$ Behavioral Economics posits a more complex model of decision-making, "one that includes unconscious motives and other factors outside the control of a purely rational process" and biases are viewed as unconscious (or beneath awareness). ${ }^{102}$ Persons reveal a tendency to give themselves "moral wiggle room" by selectively seeking out or ignoring information so as to permit "unethical behavior with an easy conscience.", 103 Disclosure may perversely "give the adviser a 'moral license' for strategic exaggeration in the adviser's best interest."104

Bazerman reiterated from his own work the concepts of "bounded awareness" in decision making and "bounded ethicality," by which he

94. See id.

95. See generally Ap Dijksteruis, et al., On Making the Right Choice: The Deliberation-Without-Attention Effect, 311 SCI. 1005 (2006).

96. See Symposium, supra note 4 , at 13.

97. See id. at 13-17.

98. See id.

99. See id.

100. See id. at 16.

101. See id. at 19.

102. See id.

103. See id. at 20.

104. See id. at 22. 
means the systematic and predictable ways in which persons act unethically beyond their own awareness. ${ }^{105}$ Bazerman referenced a quotation from Upton Sinclair: "It is difficult to get a man to understand something when his salary depends on his not understanding it ${ }^{106}$." Bazerman then drew a chilling parallel between the professions of medicine and accounting, recounting the massive corporate accounting scandals at the turn of the $21 \mathrm{st}$ Century, and the failure of the accounting profession's fiduciary responsibility to the public. ${ }^{107} \mathrm{He}$ argued that because of the cozy relations between the medical profession and its vendors, the profession might be on a similar cusp facing loss of public confidence and perceived betrayal of fiduciary responsibility. ${ }^{108}$

Comment: The pharmaceutical and device industries are well aware of the potency of their gifts, paid travels, favors and blandishments to influence physicians' choices and judgments "beneath their awareness," and they have comprehensive proprietary databases that demonstrate the effectiveness of their promotional strategies. The industry especially welcomes the vehement denials of susceptibility by their targeted physician "Key Opinion Leaders" and their indignation at the very thought they could be susceptible to the vendors' blandishments. As one former pharmaceutical CEO snorted when invited to the symposium, "We don't need science! We know they [industry's promotional tactics] work! Why the hell do you think we spend so many billions of dollars a year supporting them?"109

\section{FINANCIAL CONFLICTS OF INTEREST: WHERE THEY ARE, WHERE WE ARE}

The OIG, still ensconced on the NIH campus, followed up its earlier examination and condemnation of NIH's stewardship of the 1995 Rule by turning its attention to the awardee community and requesting from fortyone awardee institutions "detailed information" about instances of fCOI they had reported to the $\mathrm{NIH}$ and after reviewing these submissions, the OIG's second report on the topic, issued in November 2009, focused entirely on how the institutions were complying with the Rule. ${ }^{110}$ The report was scathing, its tone often skeptical or incredulous. Key exemplary Findings were: ninety percent of the sample rely "solely on the researchers' discre-

105. See id. at 25 .

106. Id.

107. See id. at 26.

108. See id. at 26-27.

109. Private personal communication, spring, 2007.

110. See OfF. OF THE INSPECTOR GEN., DEP'T OF HEAlth AND HuMAN SERV., OEI-0307-00700, How GRANTEES MANAGE CONFLICTS OF INTEREST IN RESEARCH FuNDED BY THE NATIONAL INSTITUTES OF HEALTH (2009), available at http://oig.hhs.gov/oei/reports/oei-0307-00700.pdf. 
tion to determine which of their significant financial interests" should be reported to their institutions; ${ }^{11}$ almost half the sample does not require that their faculty members' reports contain specific financial values; ${ }^{112}$ there is no routine verification of the information provided; ${ }^{113}$ there is lack of documentation of management strategies used for identified fCOIs; ${ }^{114}$ the universities are not required to report their own financial interests with outside research-related entities. ${ }^{115}$

Among the key Recommendations were that: universities should report to NIH the details of the fCOIs that they detect; ${ }^{116}$ "collect information on all Significant Financial Interests held by" their faculty researchers; ${ }^{117}$ develop methods to verify faculty members' reported financial interests; ${ }^{118}$ ensure proper documentation and enforcement of the Rule. ${ }^{119}$ Key Recommendations to the NIH were: NIH should increase its oversight and should develop new regulations that address institutional fCOIs. ${ }^{120}$

As their earlier report had clearly signaled, the OIG seemed convinced that neither the awardee institutions nor the NIH had taken the $1995 \mathrm{fCOI}$ Rule seriously enough or exercised their respectively assigned duties acceptably. The NIH's failures were in accurate record keeping, comfortably remediable within the confines of the Rule; in sufficiently vigorous oversight, somewhat vague, and troubling for that; and in its lack of oversight of awardee institutions' own related financial interests, that is, their institutional fCOIs ("IfCOIs"). Because IfCOIs were not recognized at the time, they are not mentioned in the 1995 Rule, and to address them would require a significant revision or rewriting, as the OIG recommended. ${ }^{121}$ Although, because that Rule was so wondrously light-handed, the academic community will always become anxious at any mention of its possible revision, I would nonetheless argue that NIH could respond reasonably to the OIG's recommendations without fundamental upheaval of the current fCOI regime.

But the failings of the academic community identified by the OIG touch on fundamental matters at the heart of the university's relationship with its faculty, with the NIH, and with society, all three of which are built on trust. Thus, it was natural for the universities to expect their faculty members to be dutiful and accurate in reporting their SFIs that they deter-

111. Id. at 13 .

112. Id. at 13-14.

113. Id. at 14-15.

114. Id. at 16-17.

115. Id. at 18 .

116. Id. at $19-20$.

117. Id. at 20 .

118. Id. at 21 .

119. Id.

120. Id. at 21-22.

121. See OFF. OF THE INSPECTOR GEN, supra note 56, at 18 . 
mined could be perceived to be related to their federally sponsored research proposals, and for many institutions to decide they needed to know only where those SFIs fell within broad tranches, but not specific amounts. And under the terms of the Federal-Academic Research Partnership, it was natural for the NIH to trust the universities to determine whether reported SFIs rose to fCOIs, and if so, to dispose of them appropriately and notify the agency - NIH saw no need to probe further into the details. After all, partners trust each other!

As for the universities' relation to society, they have long been expected, among other functions, to serve as independent, objective, and trustworthy sources of expert information and guidance "to the public agency in need of expert guidance and the general society in need of greater knowledge." ${ }^{\prime 22}$ But in the past half-century, and increasingly in recent decades, universities have come to be expected to serve as engines of socioeconomic development in their communities and regions, sparking the growth of new industries built on new knowledge and technologies emanating from faculty research. This diffusion of new knowledge and "knowhow" occurs in multiple ways, as has been underscored in the newly released report from the National Academies of Sciences ${ }^{123}$ - through migration into the private sector of graduate students and postdoctoral fellows, from faculty publications and consulting, from university-industry research partnerships, and from patenting and licensing faculty inventions. Although the last is the smallest share of these mechanisms, it is the most easily quantifiable and thereby, the most visible, and from the perspective of fCOIs, the most problematic. The Bayh-Dole Act legally established the university's first right to ownership of all faculty Intellectual Property ("IP") arising from federally supported research and obligated the institution to promote the transfer of that IP into the private sector for development. ${ }^{124}$ In the past three decades, university engagement in technology transfer has soared, as measured by numbers of new patents, licenses, and start-up companies, and amounts of royalty revenues. ${ }^{125}$ Less publicly visible is the amount of equity that universities and their faculty-inventors have amassed, especially in start-up companies and other early-stage venture capital deals.

Thus, not only faculty researchers but also their institutions may now have substantial financial interests in areas in which the faculty may have legitimate ongoing research interests. For the faculty, the 1995 fCOI Rule

122. Korn, supra note 38 , at 2235.

123. See Comm. on Mgmt. of Univ. Intellectual Prop., National Academy of SCIENCEs (NAS)., MANAGING UNIVERSITY INTElleCtUAL PRoPERTY IN THE PUBLIC INTEREST (National Academies Press, 2010).

124. See Patent and Trademark Act Amendments of 1980, Pub. L. No. 96-517, 94 Stat. 3015.

125. See Press Release, Association of University Technology Managers, U.S. Licensing Activity Survey (2010) (on file with author). 
defines "significant," albeit arbitrarily and without intrinsic validity; ${ }^{126}$ but what would constitute a "significant" financial interest for the university, and if there were such, what evidence would one seek to determine that the interest rises to IfCOI? Or would that determination, as with individual fCOI, rest entirely on perception? But by whom or what official body? And, if one could credibly and reproducibly reach the determination of IfCOI, what remedies would be appropriate and realistic? By what management strategies could the existence of such financial holdings be made to comport with the role of universities as "independent arbiters of knowledge?"127 It is worth noting that more than three decades ago, in 1979, Harvard University President Derek Bok famously turned down an offer of equity shares from three faculty founders of a new start-up biotechnology company, asserting in essence that a university should not go into business with its faculty. ${ }^{128}$ Perhaps Bok foresaw the wrenching difficulties that lay ahead on such a path and concluded they would not be manageable and must therefore be avoided. His statement was truly a "shot heard 'round the academic research community," and Harvard maintained this marvelously principled stance until May 1995, when its governing body determined that acceptance of such equity was acceptable. President Bok devoted most of his 1979-1980 President's Report to the Members of the Board of Overseers to the issue of academic engagement with industry. In that address, accessible in the Harvard University Archives, he stated: "[T] he causes for concern . . . . flow from an uneasy sense that programs to exploit technological development are likely to confuse the university's central commitment to the pursuit of knowledge and learning by introducing into the very heart of the academic enterprise a new and powerful motive - the search for commercial utility and financial gain."129 The academic community has come to no consensus on these knotty issues that arise from the "conflict of public expectations" and will only grow more intense as the magnitude of federal investments in science, and especially in biomedical science, continues to increase, and the public's impatience and thirst for tangible benefits - diagnostics, treatments, cures, and solutions to a whole array of pressing social problems - continue to rise.

126. See 45 C.F.R. $\S 94.3$ (2009).

127. Statement made by U.S. Rep Albert Gore during a small meeting in 1981-82 attended by the Vice President for Federal Relations at the AAU, who communicated it to Dr. David Korn shortly thereafter.

128. See generally DereK BoK, RePort of the President of HaRvard College AND REPORTS OF DEPARTMENTS: 1979-1980, 23-31 (1981), available at http://pds.lib.harvard.edu $/ \mathrm{pds} / \mathrm{view} / 2582287 ? \mathrm{n}=19039 \& \mathrm{~s}=6 \&$ print Thumbnails $=$ no.

129. DeReK BoK, RePORT OF THE President OF HARVARD College and REPORTS OF DEPARTMENTS: 1979-1980, 6-7 (1981), available at http://pds.lib.harvard.edu/pds/view/ $2582287 ? \mathrm{n}=19039 \& \mathrm{~s}=6 \&$ print Thumbnails $=$ no. 


\section{NIH IsSUES AN ADVANCED Notice OF PROPOSED RULE MAKING (ANPRM) FOLLOWED BY AN NPRM}

In spring 2009, NIH responded to the second OIG Report and Congressional prodding by issuing an ANPRM, ${ }^{130}$ soliciting the views of the research community on changes to the 1995 Rule based largely on the recommendations in the OIG Report, and in spring 2010, the agency issued a NPRM. ${ }^{131}$ Each of the Notices received outpourings of comments from an anxious academic community, facing up to the reality that the 1995 Rule was going to be changed, but perhaps not yet fully grasping that the changes were being brought about largely by their own failures to be dutiful in discharging the relatively gentle obligations the Rule had imposed upon them. At the time of this writing the NIH had not yet issued its Final Rule. The NPRM was gentler than the OIG's recommendations might have predicted, but it did nonetheless propose some important changes. Among these are: reducing by half the levels of financial interests in publicly trading companies that would be deemed significant, ${ }^{132}$ and making more clear that any equity holdings in a privately traded company would be so deemed; ${ }^{133}$ requiring faculty researchers to disclose all of their SFIs that might relate to their academic responsibilities, ${ }^{134}$ and transferring entirely to the universities the responsibility for determining which, if any of these, create fCOIs with federally sponsored research; ${ }^{135}$ requiring the institutions to report to NIH details about these fCOIs and their disposition of them, including any management plans imposed; ${ }^{136}$ requiring more stringent oversight of the fCOIs of award sub-recipients; ${ }^{137}$ requiring training in fCOI for all researchers prior to their initiating federally sponsored research and every two years thereafter; ${ }^{138}$ and requiring institutions to post on their publicly accessible websites a listing of all instances in which they had determined the existence of a fCOI. ${ }^{139}$ What did not appear in the NPRM, but was ques-

130. See NIH Requests Comments on Proposed Amendment of Regulations on the Responsibility of Applicants for Promoting Objectivity in Research for which Public Health Service Funding is Sought and Responsible Prospective Contractors, NAT'L INST. OF HEALTH, http:/grants.nih.gov/grants/guide/notice-files/NOT-OD-09-099.html (last visited Jan. 25, 2011).

131. See Responsibility of Applicants For Promoting Objectivity in Research For Which Public Health Service Funding Is Sought and Responsible Prospective Contractors, 75 Fed. Reg. 28688 (proposed May 21, 2010), available at http://edocket.access.gpo.gov/ 2010/pdf/2010-11885.pdf.

132. See, e.g., id. at 28691 (proposing that the cap for SFI's be reduced to $\$ 5,000$ as opposed to the aforementioned $\$ 10,000$ cutoff).

133. See id.

134. See id.

135. See id. at 28690.

136. See id. at 28696.

137. See id. at 28694.

138. See id. at 28705-06.

139. See id. at 28697-99. 
tioned in the ANPRM, was a requirement that institutions develop and implement IfCOI policies. Concerted push back from the community had, in my view correctly, convinced the agency that putting such an explicit requirement in the proposed rule would still be premature.

The community submitted abundant comments in response to the NPRM; interested readers can review these ad libitum on the NIH docket. ${ }^{140}$ Numerous modifications, with which I agreed, were requested in the proposed requirements, some of them substantive, many objecting to unduly onerous details of implementation. For one example, there was nearunanimous opposition to the web-posting requirement, mainly on the grounds that having a fCOI is per se neither illegal nor a violation of academic or scientific standards, nor is it a judgment about a person's character, and that the postings would yield no legitimate benefit but would constitute needless and potentially damaging violations of the privacy of the faculty members involved. For me, the most threatening proposal is the requirement that institutions provide $\mathrm{NIH}$ with details about the instances of fCOIs they determine, their review processes, their judgments made and decisions reached about the relevance and seriousness of the fCOIs, and their final dispositions by some mix of elimination, reduction, or management. Because the determination of $\mathrm{fCOI}$ is ultimately a judgment call, as are the particulars of its disposition, and there are no black and white lines to trespass (as there are, for example, in scientific misconduct), providing these details to NIH can only lead to "second-guessing" and disagreements by administrators far removed from the scene. In the Comment Letter submitted from Harvard University dated August 19, 2010 we urged that NIH engage the community to develop a formatted template on which mutually agreed minimum necessary information would be submitted to the agency, uniformly and in all instances. 141 "Minimum necessary" is the key to preventing the agency from launching fishing-expeditions that would exceedingly contentious, enormously wasteful of time and resources, as well as good will, and lead to no good end.

\section{CONCLUDING REMARKS}

It is now more than three decades since an unfortunate succession of highly publicized cases of scientific misconduct, some coupled with egregious fCOIs, brought these behaviors to the attention of the Congress and Administration and led to the first federal intrusions into the jealously protected space of oversight of the conduct of federally sponsored scientific research by university faculty. The regulation on Scientific Misconduct

140. See id. at 28688.

141. Letter from Harvard University, to the National Institutes of Health (Aug. 19, 2010) (on file with the author). 
was issued in 1989, that on individual Financial Conflicts of Interest, in 1995 . $^{142}$ The basic contours of those regulations and their carefully negotiated limits to the extent of intrusion have remained substantially unchanged during the past more than 2 decades. To quote from my 2000 JAMA Commentary on fCOIs, previously cited:

Nonfinancial and financial conflicts that can affect research differ in another important way: the oversight of nonfinancial conflicts traditionally has been left to the academic community and the professions, but during the past decade financial conflicts have become a shared and contingent responsibility of academe and the federal government. The academic community has reluctantly acknowledged the government's legitimate interest in the issue, while arguing successfully that that interest be circumscribed to ensure that research is conducted with integrity and in compliance with federal laws and regulations, and that data supporting decisions that affect public health are sound and trustworthy. These boundaries, however, are not fixed, but contingent on the diligence of the academic community in meeting the responsibilities that accompany its fiercely defended claim to the privilege of self governance and academic freedom. ${ }^{143}$

I submit that the brief history presented here of fCOIs in academic medicine, whence they came, where they went, and where they are, provides vivid substantiation of this admonition.

As the community awaits the imminent publication of NIH's new Rule on fCOIs, continues to debate the significance of fCOIs as threats to integrity across the scientific disciplines, struggles to identify the least burdensome ways of detecting and responding to fCOIs effectively but proportionately, and continues to shy away from the perhaps insoluble issue of institutional fCOI, I leave the reader to ponder several conundrums that I find vexing regarding the academy's conception of the importance of fCOIs in biasing academic work and its response to the federal Rule:

1. How much attention would the academy give to faculty members' outside financial interests and the potential conflicts they may raise if it were not for federal concerns and federal regulation?

2. Accept the propositions that fCOIs can threaten the integrity of

142. See discussion supra Part III.

143. Korn, supra note 38, at 2234-35. 
research, the well-being of human and animal research subjects, the integrity of the research training environment, the wellbeing of students and trainees, individual and institutional reputations, as well as the well-being of the public; that the goal of the 1995 Rule is to "promote objectivity in [NIH-sponsored] research," "144 and the Rule nowhere singles out research on human subjects as being exceptional; but that for the public, perceived threats to the wellbeing of human research subjects clearly trump all other considerations. What should be the universities' overarching goals in implementing fCOI policies? Should they be more robust than merely to comply with federal regulations?

3. Can/should an institution credibly discriminate among the elements listed in the preceding bullet, weigh their importance differently, and fashion their fCOI policies accordingly. How does the importance of protecting research subjects' wellbeing compare to that for protecting the integrity of the research literature? And before answering consider that biased published results about the efficacy/safety ratio for a new therapeutic or the tensile strength of a structural support can harm or kill dozens or hundreds, or thousands of persons.

4. In an era of rapidly increasing understanding of the scientific foundations of influence and reciprocity, and of COI, why do the government and academy continue to share the pretense that they can meaningfully define pre-specified levels of financial interests as "significant" irrespective of context?

5. All fCOI policies begin with the requirement of "disclosure," but recent research from Professor George Loewenstein's group $^{145}$ and others shows that disclosure, far from leading a recipient to discount advice, can actually increase the stature of the adviser and the impact of the advice. How should the academy deal with this unexpected new insight?

6. How should the academy deal with the "Conflict of Public Expectations?" How can universities and academic medical centers remain trusted, "independent arbiters of knowledge" while simultaneously fulfilling steadily intensifying public expectations that they be engines of economic development in our capitalistic economy? Is there an unmet role that the government could play in creating "buffer zones" or "safe interfaces" that would help to protect the independence and credibility of research universities while ensuring that technology transfer 
thrives?

7. Can "Assurance" survive as the foundation of the FederalAcademic Research Partnership in the 21st Century? 